\section{International science education gets bad grades}

Washington

A NEW study of school science achievement in 17 countries appears to predict disaster for the future of science in the United States, mediocrity for the Japanese and great success for Britain. But appearances can be deceptive: differences in educational systems and in the proportions of students who remain in school through to the final year greatly influence the final rankings.

The study, conducted by the International Association for the Evaluation of Science Achievement in 1983-86, reports the results of tests in the basic concepts of biology, physics and chemistry taken by some 44,000 students in their last year of school. All the students who participated in the study were enrolled in science courses. The results, showing Britain near the top of the rankings and the United States near the bottom, are summarized in the table below.

Specialization partly explains the successes scored in Britain, Hong Kong and Singapore. In their final years, students in these countries are concentrating their efforts in only two or three subjects. But more important is that only one-fifth of the age-group eligible to be in the last year of school is actually enrolled, leading the authors of the report to ask whether the high performance of this elite is obtained at the expense of mass education. In comparison, the United States retains three-quarters of its high-schoolage children in school to the final year, and Japan retains almost all its students.

Even though the United States and Japan have good records for educating the majority of their populations, problems are still evident. Advanced science stu-

Ranking according to science achievement in final year in school

\begin{tabular}{lll}
\hline Biology & Chemistry & Physics \\
Singapore & Hong Kong & Hong Kong \\
England & England & England \\
Hungary & Singapore & Hungary \\
Poland & Japan & Japan \\
Hong Kong & Hungary & Singapore \\
Norway & Australia & Norway \\
Finland & Poland & Poland \\
Sweden & Norway & Australia \\
Australia & Sweden & United States \\
Japan & Italy & Sweden \\
Canada & United States & Canada \\
Italy & Canada & Finland \\
United States & Finland & Italy
\end{tabular}

Data for Korea, the Netherlands, the Philippines and Thailand were not available for these categories. All data from Science Achievement in Seventeen Countries (US National Science Foundation, Office of Studies and Program Assessment, Washington, DC, 1988). dents in the United States - those who have studied a subject for more than one year - perform poorly compared to the best students from Britain. The study concludes that "for a technologically advanced country, it would appear that a reexamination of how science is presented and studied is required". Japanese science students show a large gap in their knowledge of biology compared to their performance in physics and chemistry, and significant differences in science achievement show up between students of various schools, suggesting that educational opportunity is not equitably distributed.

The difference in the level of science achievement between boys and girls is still high in most countries, according to the study. Boys performed better than girls in all subjects except biology in nearly every country; only in Australia, Hong Kong
Sydney

Australia and Japan are to conduct a joint $\mathrm{A} \$ 5$ million study of the feasibility of building an international high-technology city somewhere in Australia. The city, with a population of 250,000 , would be built around government and private research institutes and high-technology industries. A total investment of some A $\$ 1,000$ million would be expected, most of it coming from private industry.

The plan is the brainchild of Japan's Ministry of International Trade and Industry (MITI), and has its origins in Japan's 'technopolises', regional centres chosen for government grants to help stimulate the growth of high-technology industry. But the Australian project is much bigger in scale. MITI has already coined a new word to describe the new city - 'multi-function-polis' or MFP.

MITI first put forward the plan early last year. A MITI delegation is now touring Australian state governments, all of which, with the exception of Tasmania, are clamouring for MFP to be built within their borders.

Given Japan's wish for the city to have a resort-like environment, the prime contender must be on Queensland's Gold Coast, near Brisbane. MITI wants the new city to provide researchers and their families with a lifestyle, integrating work and leisure, that cannot be achieved in overcrowded Japan.

Australia can offer Japan a good climate and plenty of space for the city. Brisbane is in a neighbouring time zone to and Sweden did girls score slightly higher than boys.

Three more reports will be issued in 1989 on how variations in science curricula affect performance, on specific differences in achievement between and within countries, and on changes in science achievement analysed by comparing test results from 1970 and $1983-86$.

Carol Ezzell

\section{AIDS agreement}

\section{London}

THE principal medical research organizations of France and Britain have signed a formal agreement on cooperation in AIDS research. Under the agreement, the Institut National de la Santé et de la Recherche Médicale and the Medical Research Council will retain their own programmes of AIDS research but will take part in a variety of joint activities, such as meetings and exchanges. In addition, there may be joint financial support for some research undertaken in each country. Simon Hadlington

\title{
Japan's high-tech planners dream of Australia's beaches
}

Tokyo. And Australia is seen as an advanced country with a strong research base which is not a serious competitor in high technology. Australia could also provide a neutral ground for researchers from Japan, Europe and the United States

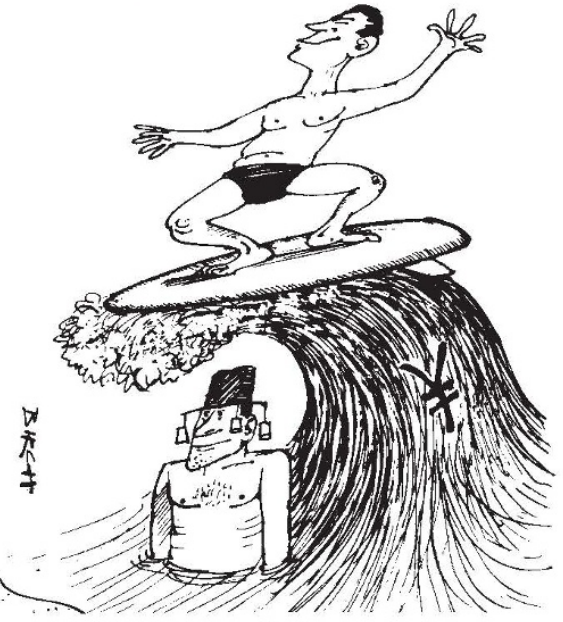

to mingle. Research institutes and corporations from around the world, and particularly from the United States, will be invited to set up facilities in the city.

For Japan, the city would be an experiment in twenty-first century living which could become a prototype for other cities on the Pacific rim. For Australia, according to Senator John Button, Minister for Industry, Technology and Commerce, the city would be an opportunity for Australian industry to leap into a new realm of innovation and development.

Charles Morgan 